\title{
Informal Finance and Asymmetric Information: A Theory Review
}

\author{
Wei Zhao ${ }^{1,2}$ \\ ${ }^{1}$ School of Economics and Resource Management, Beijing Normal University, Beijing, China \\ ${ }^{2}$ Chairman Office, Agriculture bank of china, Beijing, China \\ Correspondence: Wei Zhao, School of Economics and Resource Management, Beijing Normal University, Beijing, \\ China.
}

Received: December 28, 2016

Accepted: February 22, 2017

Available online: February 27, 2017

doi:10.11114/aef.v4i2.2248

URL: https://doi.org/10.11114/aef.v4i2.2248

\begin{abstract}
Based on theories of financial inhibition and Transaction Cost Theories, along with the combination of behavior economics, this paper tries to discuss and analyze the nature of informal finance. In china, it is hard to finance for Mid-small business, informal finance has advantage to deal with the capital gap of Mid-small size business as a supplementary means of formal finance which are hard to overcome the problem of adverse selection and moral hazard induced by asymmetric information. we discussed the foundation for existing of informal finance and objective necessity. Based on perspective of asymmetric information, we tried to answer why informal finance still thrived vibrantly on the process of financial deepening.
\end{abstract}

Keywords: informal finance, formal finance, interest rate control, credit rationing, asymmetric information, moral hazard, adverse selection

\section{The Foundation of Institution of Informal Finance}

\subsection{Control of Interest Rate and Discrimination of System}

Financial inhibition featured characteristics by means of setting the Interest Rate Ceilings, controlling the financial resources, and realized the purpose that government take bank as the second treasury. As Yi Fu Ling (2005) said, it is the inevitable choice that china had to give priority to develop the Capital-intensive heavy industry on the lack of precious financial resources. In addition, Chinese government had to strength the control of finance resources to achieve the goal of development because the reform of continuously deepening fiscal system impaired and weaken the adjusting control capacity of macroeconomy on the transformation of china from planned economy to market-oriented economy (Shen, 2016). For this reason, Chinese bank adopted the branch banking system, lowering the cost of financial resources of adjustment and allocation by government. On the top level, government taken control of almost every bank which was labeled as stated-owned, allowing central bank making policy through strictly interest rate control (Wang, 2001) and credit rationing.

Interest rate control had two side effect of foundation of institution for the emergence and development of informal finance. In view of supply-side, interest rate control produced the extremely low interest of deposit, and the interest rate had been distorted. The interest rate cannot reflect the true preference of depositor. So, Depositors have a burning desire to gain the high income of deposit from the informal financial market. That was called "Financial Disintermediation". This process exactly provided the capital resource for the informal finance. In view of demand-side, interest rate control make the commercial bank loan rate not to reflect the true market rate which represented the extent of scaring of capital, let alone the marginal productivity of capital (Zeng \& Song, 2008). In addition, government issued some special policy to encourage the development of strategic emerging industry, in turn, these enterprises are too extreme about financing. 


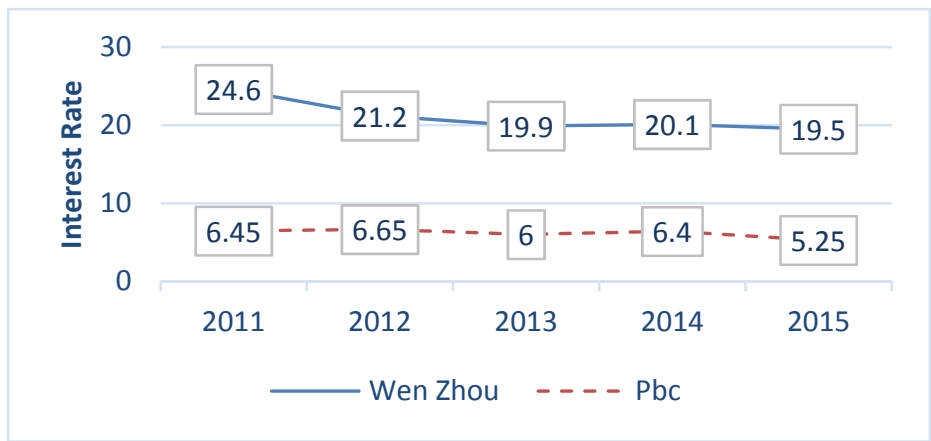

Figure 1. People's bank of china and Wen Zhou (2011-2015) 5-year loan rate comparison ${ }^{1}$

Based on Law of supply and demand (Curbelo, 2000), Strict interest control will lead to serious supply and demand of capital imbalance. In fact, Chinese bank sector have been enjoying the enormous interest spreads of deposit and loan as Table 1 shows (Tang \& Yan, 2007).

Table 1. Loan, deposit interest and spread (1999-2016) in China ${ }^{2}$

\begin{tabular}{ccccccccccc}
\hline year & $\mathbf{1 9 9 9}$ & $\mathbf{2 0 0 2}$ & $\mathbf{2 0 0 4}$ & $\mathbf{2 0 0 6}$ & $\mathbf{2 0 0 8}$ & $\mathbf{2 0 1 0}$ & $\mathbf{2 0 1 2}$ & $\mathbf{2 0 1 4}$ & $\mathbf{2 0 1 5}$ & $\mathbf{2 0 1 6}$ \\
\hline loan & 5.85 & 5.31 & 5.58 & 6.12 & 6.93 & 5.85 & 6.4 & 5.75 & 5 & 4.35 \\
deposit & 2.25 & 1.98 & 2.25 & 2.52 & 2.25 & 2.75 & 3 & 2.55 & 1.5 & 1.5 \\
spread & 3.6 & 3.33 & 3.33 & 3.6 & 4.68 & 3.1 & 3.4 & 3.2 & 3.5 & 2.85 \\
\hline
\end{tabular}

Household lacked effective investment channels so that money flowed into state-own bank because of the financial control. In addition, part of the capital from family had been used to speculate in security, bond, property market, even gambling. Capital can find its way to avoid the regulation and rules which blocked the way it went through just like river from high level can steer clear of obstacle. It is the nature that capital always pursued profit maximization. On the other hand, based on the severe ownership prejudice and institutional discrimination formal financial entity were inclined to carry out credit rationing on the background that domestic savings is larger than domestic investment. Amount of capital were distributed to government priorities and state-owned business but the privately-run business and township enterprise which emerged on the market economy process have hardly any chance to get capital to expand production and buy new device (Potter \& Simon, 2014). The main form of discrimination is scale discrimination which means that enterprise hardly get capital support from formal financial institution in the primary stage. That is refer to "the problem of financing of Mid-small size companies" (Shen, Shen, Zhong, \& Ying, 2009).

As the table 2 shows that along with the increase of scale of the business, commercial bank loan increased correspondingly. Apart from the scale discrimination, institutional discrimination also is major reason for the problem of financing of Mid-small size companies. Non-state economic sectors only got limited loan support from formal finance (Cull, Xu, \& Zhu, 2007).

Table 2. Registered capital structure of Mid-Small enterprise in Shan Xi province of China

\begin{tabular}{ccccccc}
\hline Registered capital & \multicolumn{7}{c}{ Source } \\
\cline { 2 - 7 } (unit ten thousand) & self & relative & policy-related loan & venture capital & commercial bank loan & others \\
\hline $\mathbf{5 0}$ below & $72.60 \%$ & $21.30 \%$ & $2.80 \%$ & 0 & 0 & $3.30 \%$ \\
$\mathbf{5 0 - 1 0 0}$ & $69.50 \%$ & $27.50 \%$ & $1.20 \%$ & 0 & 0 & $1.80 \%$ \\
$\mathbf{1 0 0 - 5 0 0}$ & $66.27 \%$ & $17.50 \%$ & $3.32 \%$ & 0 & $8.73 \%$ & $4.18 \%$ \\
$\mathbf{5 0 0 - 1 0 0 0}$ & $69.10 \%$ & $2.78 \%$ & $14.45 \%$ & $0.00 \%$ & $12.22 \%$ & $1.45 \%$ \\
$\mathbf{1 0 0 0}$ above & $65.70 \%$ & $2.60 \%$ & $6.45 \%$ & $1.11 \%$ & $15 \%$ & $8.97 \%$ \\
\hline
\end{tabular}

\footnotetext{
${ }^{1}$ Data resource: Wind Data and Official web of People's bank of china

${ }^{2}$ Data resource: Official web of People's bank of china
} 
Table 3. Non-state entity loan ratio from formal finance ${ }^{3}$

\begin{tabular}{ccccc}
\hline Year & $\begin{array}{c}\text { Private } \\
\text { business }\end{array}$ & $\begin{array}{c}\text { Village } \\
\text { enterprise }\end{array}$ & peasant household & $\begin{array}{c}\text { Non-state } \\
\text { sector }\end{array}$ \\
\hline $\mathbf{2 0 0 3}$ & $1.75 \%$ & $9.16 \%$ & $10.05 \%$ & $20.96 \%$ \\
$\mathbf{2 0 0 4}$ & $2.39 \%$ & $0.29 \%$ & $11.33 \%$ & $23.01 \%$ \\
$\mathbf{2 0 0 5}$ & $2.49 \%$ & $9.04 \%$ & $13.26 \%$ & $24.79 \%$ \\
$\mathbf{2 0 0 6}$ & $2.71 \%$ & $6.31 \%$ & $13.41 \%$ & $22.43 \%$ \\
$\mathbf{2 0 0 7}$ & $3.06 \%$ & $6.22 \%$ & $13.48 \%$ & $22.76 \%$ \\
$\mathbf{2 0 0 8}$ & $3.37 \%$ & $5.96 \%$ & $14.08 \%$ & $23.41 \%$ \\
\hline
\end{tabular}

In recent years, along with the continuously deepening of the financial market (Wang, 2014), formal finance provided more support for non-state sector, the outcome still is not positive. In addition, government and regulators rolled out the middle and small capital stock and Growth Enterprises Market in china, but because the screening mechanism was very strictly, there were plenty of Middle and small business which had no chance to access to financing. So, they just shifted to pursue help from the informal financial channel to credit (Wang \& Zhang, 2003).

Interest rate control and credit rationing which have been included in financial inhibition hypothesis, induced the extra capital supply and demand out of formal finance, that is why informal finance existed.

\subsection{Finance Inhibition}

We try to analyze the system origin of informal finance with partial equilibrium. We start it with interest rate control and credit rationing of finance inhibition.

$\mathrm{S}(\mathrm{r})$ is capital supply function which capital stakeholder decide and $\mathrm{D}(\mathrm{r})$ represent the capital demand function which capital demander decide, as the Figure 2 shows:

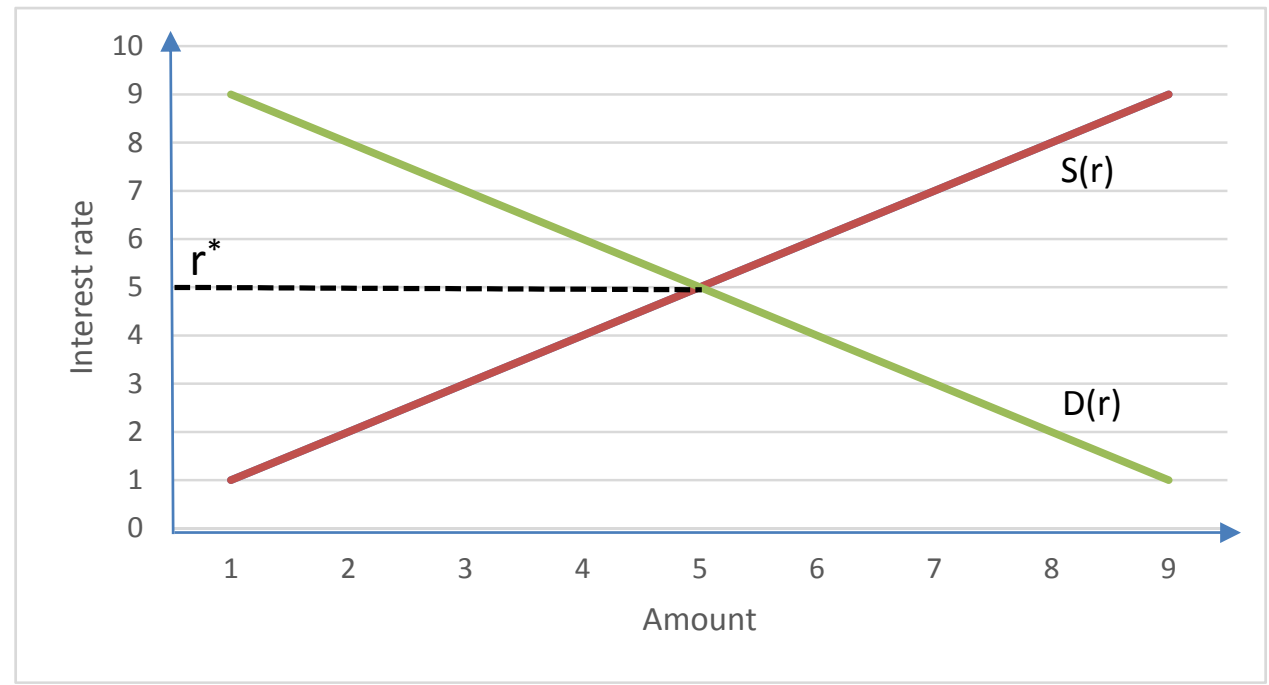

Figure 2. Equilibrium interest rate in the free competition market

${ }^{3}$ Data source: ALMANAC OF CHINA'S FINANCE AND BANKING (1986-2009) 


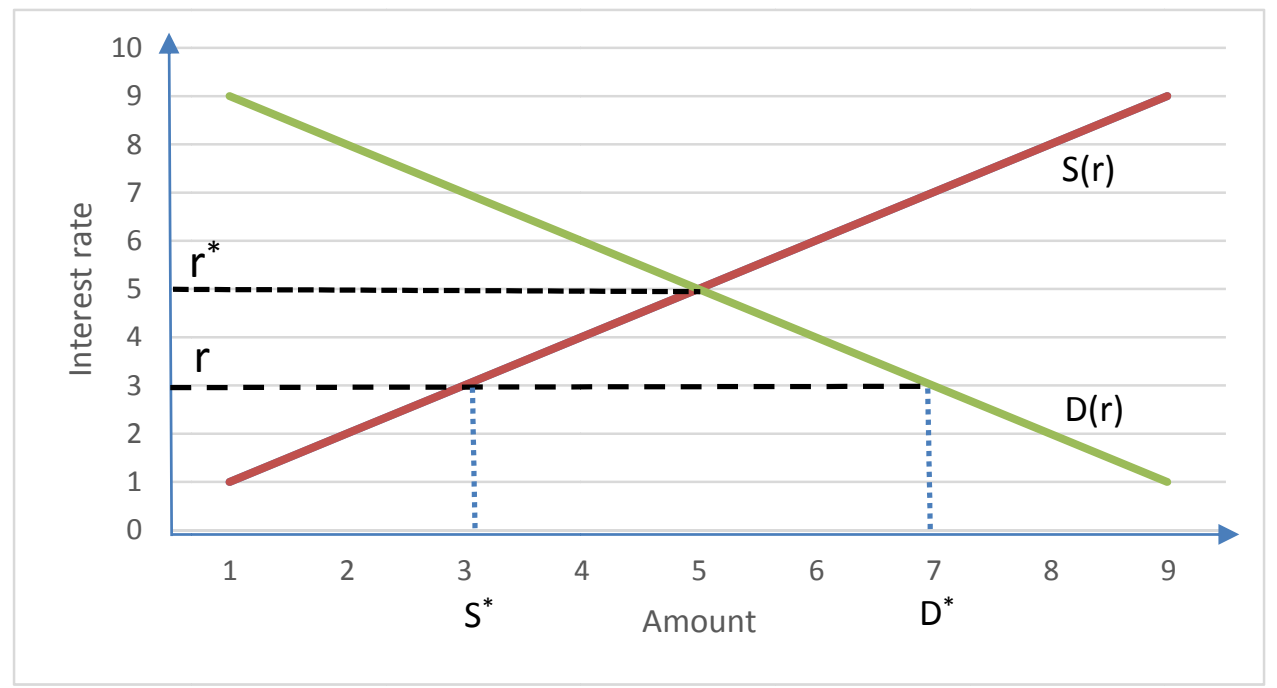

Figure 3. Capital shortage and demand surplus on the condition of interest control

In the free competition market, the two sides of capital supply and demand are easy to reach an agreement and sign a credit contract. Finally, thousands of capital traders bargain to form the equilibrium interest rate $r^{*}$. But if government set the interest ceiling to execute the interest control, as the Figure 3 shows:

On the condition of interest rate control, bank interest rate is lower than the equilibrium interest rate $r<r^{*}$, capital supply is less than capital demand $\mathrm{S}^{*}<\mathrm{D}^{*}$, the gap $\left(\mathrm{D}^{*}-\mathrm{S}^{*}\right)$ is the result of interest rate control of finance inhibition. The formal financial institution for example bank, security, and insurance are not allow to lend money for the Mid-small size business, so they had to turn to the informal finance to get money to resolve their production and financial problem (Jaffee \& Russell, 1976).

what if government and regulator execute the credit rationing? As Figure 4 shows:

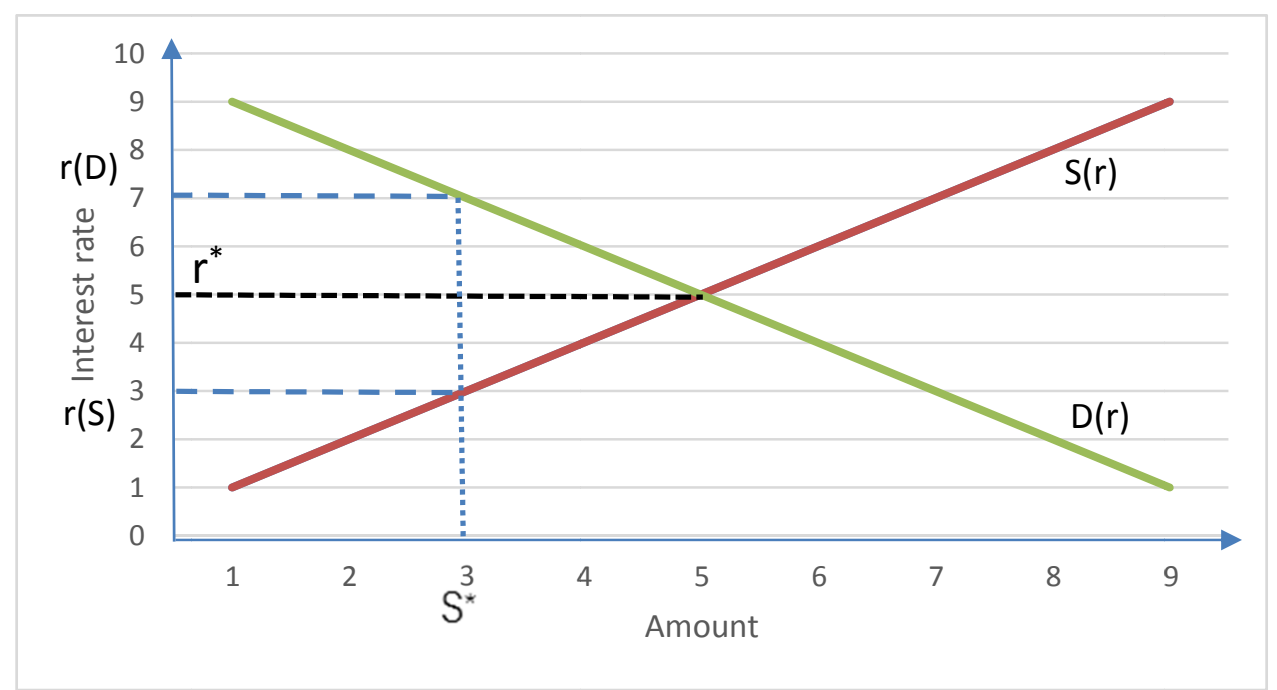

Figure 4. Nominal interest rate and real interest rate on the condition of credit rationing

If government execute the $\mathrm{S}^{*}$ credit rationing, then the interest rate of formal finance is $\mathrm{r}(\mathrm{S})$, and the capital demand interest rate is $r(D), r(S)<r(D)$. It indicates that capital demander borrowing interest rate is much higher than the capital supplier lending interest rate on the condition of credit rationing, also higher than the nominal interest rate declared by the bank. Because market decides the informal financial interest rate which reflected the true interest rate the formal financial institution faced, that explained why informal interest rate always is higher than interest rate of formal finance.

\section{Asymmetric Information and Mechanism of Trading}

Interest rate control and credit rationing under financial inhibition are the nature of system discrimination, then Asymmetric information (Sharpe, 1987) and trading cost theory explain the reason of informal finance from perspective of mechanism of trading. 


\subsection{Information Screening (Cornell \& Welch, 1996), Interest Rate and Expected Revenue}

We can see that informal finance prevailed among the advanced countries proved that the credit rationing still exist under regulating-free and advanced formal finance. In the view of basic supply and demand economic theory, if demand is higher than supply, the price will rise until going to the equilibrium price. If things go along with this kind of logic, credit rationing has no foundation of existence. As Stiglitz and Weiss (1981) said that credit rationing just like the unemployment problem in the labor market, it was caused by the surplus of labor supply or the surplus of capital demand on the surface. in fact, long-run imbalance and short-run imbalance are the main reason for the unemployment problem (Wang \& Zhang, 2003).

The short-run imbalance is that when the economy was hit by external shock, interest rate hold to still. During the process of returning to equilibrium state, credit rationing will emerge; the long-run imbalance is that owing to the asymmetric information which lead to adverse selection and Moral Hazard, the relationship between expected revenue of bank and loan rate are not the monotonic increasing, so formal financial institutions must execute credit rationing to protect their profit.

The expected revenue of formal financial institutions includes two part, one is the price of capital or interest rate, another is the risk of loan or probability of default of borrowers. We suppose that the risk of loan is independent of the capital price, when the demand of capital is bigger than the supply of capital, bank will increase the amount of supply to increase the profit along with the interest rate rising. But the fact was not what we thought, when formal financial institutions were hard to observe the risk characteristic of borrowers and investors, the true capital price played a role to screen to see the risk, the rising of capital price squeezed the borrowers of lower risk and revenue out, that is what we called "adverse selection" that push both the price of capital and risk of lending rising. On the other side, the rising of price of capital which forced borrowers to select high revenue and high risk project is incentive mechanism. In turn, the high revenue and risk project increased the probability of default of borrowers. The two of capital effect both increased the probability of default that the borrowers who are willing to pay high interest rate are just the high-risk one. So, the rising of capital price increased the risk of lending, and lowering the expected revenue of bank in reverse. Based on the paradox, the formal financial institutions are inclined to operate credit rationing on the low level of interest rate rather than clearing market (Zeller, 2000).

As the Figure 5 shows, $r$ represents the interest rate of bank, $Y$ the expected revenue, $r^{*}$ the optimal loan rate of bank. When $r<r^{*}$, revenue effect is higher than risk effect when interest rate is rising, $Y$ is increasing along with the rising of $r$; when $r>r^{*}$, revenue effect is less than risk effect when interest rate is rising, $Y$ is decreasing along with the rising of $r$.

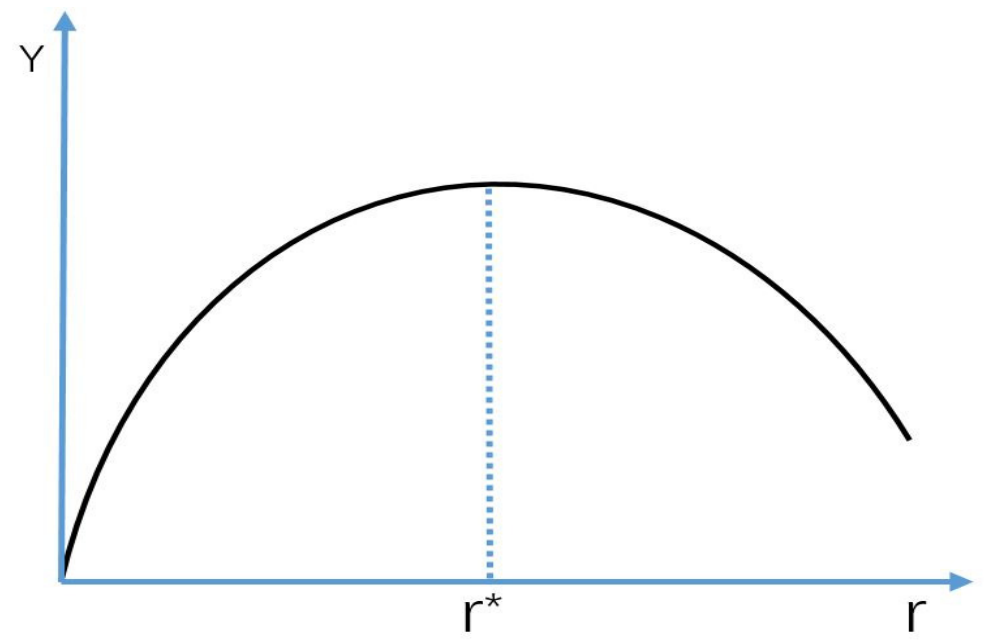

Figure 5. The expected revenue and interest rate of formal financial institution

\subsection{Credit Rationing Induced by Moral Hazard}

The formal financial institutions prevented asset from risk of default to operate credit rationing. As for formal financial institutions, which's function nearly are indirect financing, it means that formal financial institutions cannot manage the asset project directly by themselves. That situation make it difficult that lenders know clearly the exact purpose of capital and progress of project. The principal-agent relationship between the bank and borrower is the main source of moral hazard in the lending market (Lízal \& Svejnar, 2006).

The moral hazard in the lending market included two types: one is that borrower take a risk to pursue high yield, investing money to high risk and high return asset which have high probability of default; the other one is that 
borrowers can repay the loan, but they are not willing to pay back after they compared the two choice between default cost and revenue, and finally they choose strategic default. We found that the relationship between the expected revenue of formal financial institutions and loan rate is not the monotonic, that lead bank to operate credit rationing like what adverse selection theory reveal.

Stephen D. Williamson (1986) explained from the perspective of moral hazard that Costly State Verification Paradigm provided good theoretic explanation for credit rationing. Under the huge monitoring cost, formal financial institutions often choose the option of credit rationing considering the potential default risk of borrowers, although establishment of the financial institution mechanism is to save the information and trading cost because of scale economy theory.

\subsection{The Geometric Description of Credit Rationing}

We suppose that there existed asymmetric information between formal financial institutions and borrowers, the probability of default of borrower is $\mathrm{v}$, and formal financial institutions only know the probability distribution of $\mathrm{v}$ rather than the exact probability of default of each borrower. Formal financial institutions hardly acquired comprehensive information about the borrowers under the condition of asymmetric information, but borrowers known the risk or in another word they known themselves and were inclined to report the information which are in favor of getting a loan, conceal the fact which are not good for loan.

For the formal financial institutions, we suppose that the expected revenue of loan is $\mathrm{Y}$ which is function about interest rate $\mathrm{r}$ and probability of default $\mathrm{v}, \mathrm{Y}=\mathrm{Y}(\mathrm{r}, \mathrm{v})$. If formal financial institutions know the comprehensive information about the borrowers, they can determine every specific interest rate in the light of the probability of default of each borrower, then maximizing the expected revenue Y. Following the reasoning, we suppose that formal financial institutions set the interest rate as $\mathrm{r}^{*}$ when the probability of default of borrower is $\mathrm{v}^{*}$, then all the borrowers whose probability of default $\mathrm{v}>$ $v^{*}$ will get the interest rate $r>r^{*}$. There existed a paradox for formal financial institution that interest rate will increase along with the rising of probability of default of borrowers, but the rising of interest rate pushed the lowering probability of default of borrowers out of the credit market, the risk formal financial institutions face increased correspondingly.

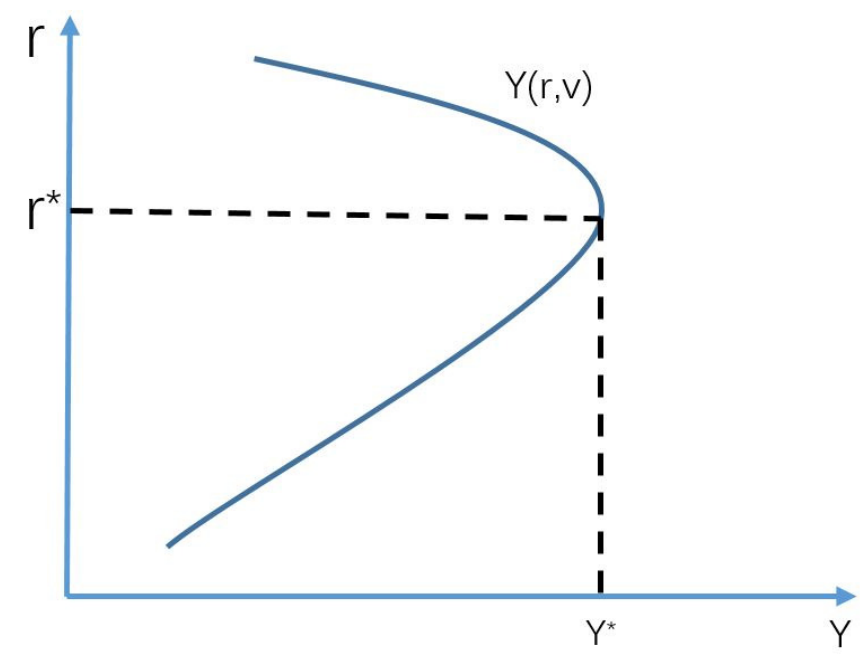

Figure 6. The expected revenue of formal financial institution and interest rate

Figure 6 shows that $\mathrm{Y}=\mathrm{Y}(\mathrm{r}, \mathrm{v})$ is the non-monotonic curve of expected revenue about formal financial institutions. When $r>r^{*}$, the expected revenue of formal financial institutions will decrease along with the rising of interest rate because of adverse selection which was induced by asymmetric information. 


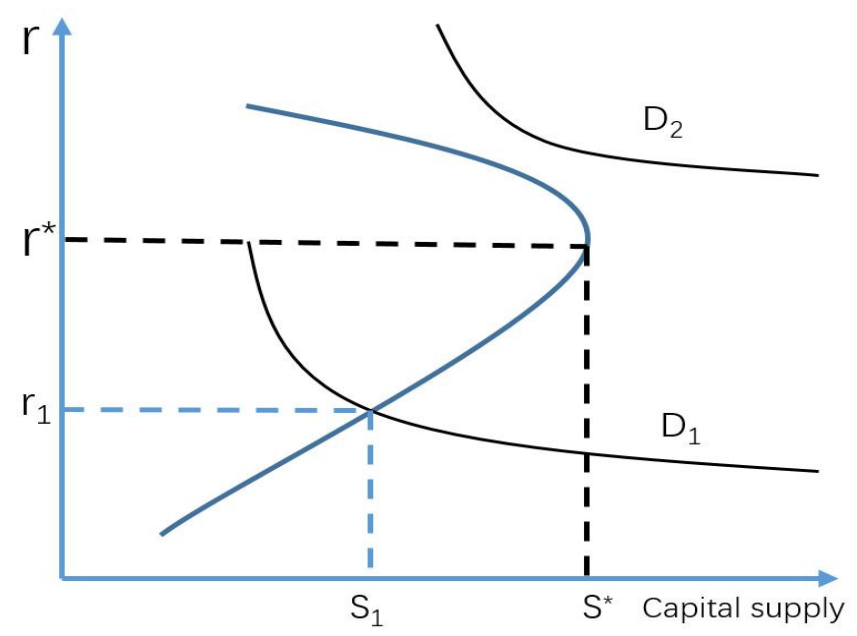

Figure 7. The supply curve of loan and interest rate

Figure 7 shows that the supply curve of loan is $\mathrm{S}$ which is like the cure of expected revenue of formal financial institutions. If the demand curve of whole market is $\mathrm{D}_{1}$, the market will reach the competitive equilibrium price $\mathrm{r}_{1}$ which cleared the market; if the demand curve of whole market is $\mathrm{D}_{2}$, then formal financial institutions will determine the interest rate as $\mathrm{r}^{*}$ which maximized the expected revenue through credit rationing.

Figure 8 shows the symmetric relationship between risk of loan of formal financial institutions and interest rate. $\left(\mathrm{r}^{*}, \mathrm{v}^{*}\right)$ represent that the combination of interest rate and risk of loan when it reaches the equilibrium point of credit rationing, the interest rate will tend to be infinite when the probability of default of borrowers tend to be infinite.

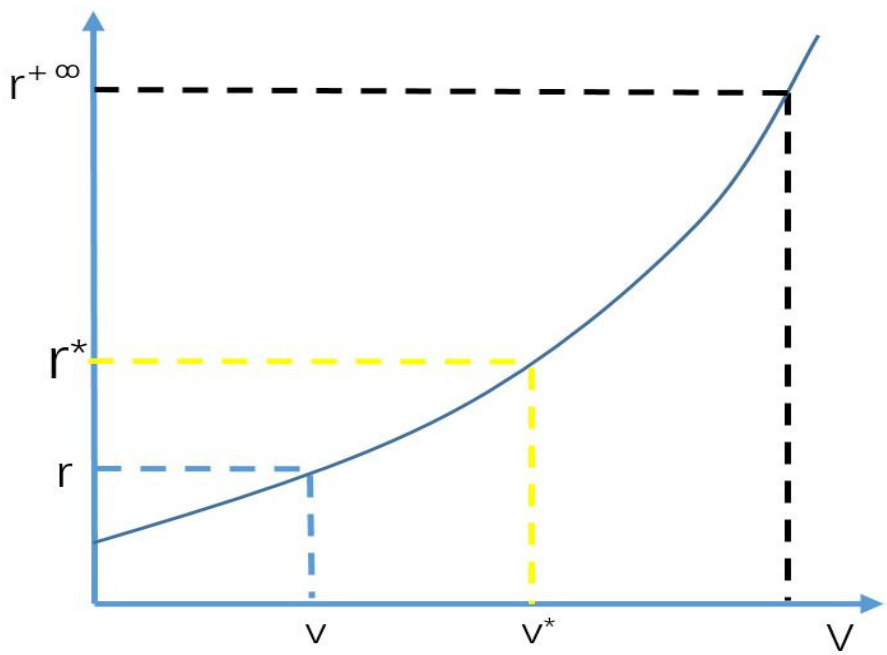

Figure 8. The risk of loan about formal financial institutions and interest rate

\section{Conclusion}

The credit rationing and interest rate control based on the asymmetric information theory did not directly explain the reason why informal finance emerged and existed, but it revealed the principle of endogenous from which informal finance obtained the room of survival and development. Formal financial institutions faced the paradox that probability of default borrowers is increasing correspondingly along with the rising of interest rate for profit. So, we found that credit rationing and interest rate control would be the inevitable choice to deal with the risk for formal financial institutions. On the contrary, the credit rationing and interest rate control induced by asymmetric information strengthened the effect of financial inhibition and provide the soil to support the survival and development of informal finance. In the future, we need keep researching to use empirical data in china to prove that presence of informal credit markets can reduce the cost of credit rationing, and alleviate the impact of asymmetric information based on the available information. 


\section{References}

林毅夫, \& 孙希芳. (2005). 信息、非正规金融与中小企业融资. 经济研究, (7), 35-44.

Cornell, B., \& Welch, I. (1996). Culture, information, and screening discrimination. Journal of Political Economy, 104(3), 542-571. https://doi.org/10.1086/262033

Cull, R., Xu, L. C., \& Zhu, T. (2007). Formal finance and trade credit during china's transition. Policy Research Working Paper, 18(2), 173-192.

Curbelo, S. (2000). The law of supply and demand. Mathematica Scandinavica, 3(3), 16-16.

Jaffee, D. M., \& Russell, T. (1976). Imperfect information, uncertainty, and credit rationing. Endocrinology \& Metabolism Clinics of North America, 90(4), 651-666. https://doi.org/10.2307/1885327

Lízal, L., \& Svejnar, J. (2006). Investment, credit rationing, and the soft budget constraint: evidence from czech panel data. Ssrn Electronic Journal, 84(363), 353-370.

Potter, \& Simon, M. (2014). Interest rate control during normalization. Speech.

Sharpe, S. A. (1987). Asymmetric information, bank lending, and implicit contracts: a stylized model of continuing relationships. Special Studies Papers.

Shen, Y. F., Ming-Jiang, Y. U., \& Business, S. O. (2016). A study on independent innovation of financial support system of china's small and medium-sized scientific and technological enterprises. Journal of Anhui University of Technology.

Shen, Y., Shen, M., Zhong, X., \& Ying, B. (2009). Can more small and medium sized banks provide more loans to small and medium sized enterprises? evidence from china.

Stiglitz, J. E., \& Weiss, A. (1981). Credit rationing in markets with imperfect information. American Economic Review, 71(3), 393-410.

Tang, A. B., \& Yan, L. I. (2007). Empirical Analysis on the Effect of Monetary Policy Variables on Small and Mid-sized Business Investment. West Lake International Confernece on Small \& Medium Business.

Wang, G. (2001). Interest rate control and market-oriented interest rate in china. Economic Research Journal.

Wang, Q., Department, M., \& Party School of. (2014). Deepening reform of the financial system and improving the financial market system__ learning the third plenary session of the 18th cpc central committee. Journal of the Party School of Shengli Oilfield.

Wang, X. A., \& Zhang, J. (2003). On the bank credit rationing and loan of small and medium-sized enterprises (smes). Economic Research Journal.

Wang, X. A., \& Zhang, J. (2003). On the bank credit rationing and loan of small and medium-sized enterprises (smes). Economic Research Journal.

Williamson, S. D. (1984). Costly monitoring, financial intermediation, and equilibrium credit rationing. Journal of Monetary Economics, 18(2), 159-179. https://doi.org/10.1016/0304-3932(86)90074-7

Zeller, M. (2000). Determinants of credit rationing: a study of informal lenders and formal credit groups in madagascar. World Development, 22(12), 1895-1907. https://doi.org/10.1016/0305-750X(94)90181-3

Zeng, C., Wu, J., \& Song, J. (2008). An empirical evidence of small business financing in china. Management Research News, 31(12), 959-975. https://doi.org/10.1108/01409170810920666

\section{Copyrights}

Copyright for this article is retained by the author(s), with first publication rights granted to the journal.

This is an open-access article distributed under the terms and conditions of the Creative Commons Attribution license which permits unrestricted use, distribution, and reproduction in any medium, provided the original work is properly cited. 